\title{
Bushmeat hunting around a remnant coastal rainforest in Côte d'Ivoire
}

\author{
S. Gonedelé Bi, Inza Koné, J.C.K. Béné, E.A. Bitty, K.A. Yao \\ B. A. KOUASSI and P. GAUBERT
}

\begin{abstract}
For most Ivorian regions quantitative data on the exploitation of bushmeat by local communities are scarce. We studied hunting patterns around Dassioko Sud Forest Reserve, a remnant coastal forest in south-eastern Côte d'Ivoire, through a 6-month survey of nine restaurants, in three villages surrounding the Reserve. We collected quantitative and qualitative data on the bushmeat brought to restaurants, as well as the final price for which it was sold. We calculated mean prices over the study period and extrapolated to the whole year. A total of 376 mammals (98\%) and eight reptiles ( $2 \%)$ were sold in the restaurants surveyed. Rodents and small antelopes represented $74 \%$ of the mammals sold, probably reflecting the fact that reproductive strategists persist more successfully in heavily hunted and/or agricultural landscapes, such as the area around the Reserve. Our conservative estimate of the total biomass of bushmeat harvested annually around the Reserve is c. $40,428.03 \mathrm{~kg}$ (c. 11,886 animals), with a monetary value of c. FCFA 47,728,516 (c. USD 93,485.75), yielding an annual income of c. USD10,387.31 per person, which exceeds the mean annual income of cocoa farmers (FCFA 466,032/ USD 932) more than tenfold. Although the sustainability of the bushmeat trade in the surveyed area remains unknown, we showed that hunters predominantly used cable snares, the Reserve was significantly affected by hunting activities (c. $53 \%$ of the bushmeat originated there), and larger mammalian species had been extirpated. A lack of effective protection exposes the Reserve to multiple illegal activities, including hunting, a situation exacerbated by the political crisis in 2010.
\end{abstract}

Keywords Bushmeat market, Côte d'Ivoire, coastal forest, forest reserve, wildlife conservation

S. Gonedelé Bi ${ }^{\star}$ (Corresponding author) and B.A. KouAssi Departement de Génétique, Université Félix Houphouët Boigny d'Abidjan-Cocody, 22 BP 582 Abidjan 22, Côte d'Ivoire. E-mail gonedelebi@yahoo.fr

InZA KonÉ, J.C.K. BÉnÉ†, E.A. BITTYł and K.A. YAOł Centre Suisse de Recherches Scientifiques en Côte d'Ivoire, Abidjan, Côte d'Ivoire

P. Gaubert Institut des Sciences de l'Evolution de Montpellier, Université de Montpellier, Montpellier, France

*Also at: Centre Suisse de Recherches Scientifiques en Côte d'Ivoire, Abidjan, Côte d'Ivoire

$\dagger$ Also at: Unité de Formation et de Recherche d'Environnement, Université Jean Lorougnon Guédé, Daloa, Côte d'Ivoire

¥Also at: Laboratoire de Zoologie et Biologie Animale, Université Félix Houphouët Boigny d'Abidjan-Cocody, Abidjan, Côte d'Ivoire

Received 11 May 2015. Revision requested 7 July 2015.

Accepted 23 December 2015. First published online 25 April 2016.
To view supplementary material for this article, please visit http://dx.doi.org/10.1017/So030605315001453

\section{Introduction}

$\mathrm{B}$ ushmeat describes any non-domesticated terrestrial B mammal, bird, reptile or amphibian harvested for food (Nasi et al., 2008). It represents a valuable non-timber forest product across tropical Africa, Asia and the Neotropics (Robinson \& Bennett, 2004). Since the mid 1990 os there has been an important transition from subsistence to commercial hunting (e.g. Wilkie \& Carpenter, 1999; Fa \& GarciaYuste, 2001), and the bushmeat trade is now considered to be one of the most important threats to biodiversity in the tropics (Milner-Gulland \& Bennett, 2003; Harrison, 2011).

In tropical Africa bushmeat is a significant source of animal protein (Bennett \& Robinson, 2000; Wilkie et al., 2005) and is a vital component of food security and income for rural communities (Fa et al., 2003; Nasi et al., 2008; Mbete et al., 2011). Although illegal in many countries, the bushmeat trade is a flourishing economic activity. Following socioeconomic transformations, including increased pressures from burgeoning human populations and commercial logging, and the generalized use of firearms, bushmeat hunting has reached unsustainable levels for many mammalian species (Nasi et al., 2008; Jenkins et al., 2011) relative to their rarity and distribution (Fa et al., 2014), leading to the local extinction of vulnerable species (Oates et al., 2000; Cowlishaw et al., 2005). One of the main economic factors driving the exponential increase in bushmeat offtake is the increasing demand for wild meat in urban areas, which has resulted in the establishment of urban bushmeat markets supplied by a multitude of, sometimes remote, hunting sites (e.g. Edderai \& Dame, 2006).

In western Africa aggressive politics of agricultural expansion and logging have resulted in the loss of c. $80 \%$ of the original rainforest cover, which is now fragmented into vulnerable, isolated patches (Norris et al., 2010). In such a context bushmeat hunting and habitat loss are the major drivers of extinction in wildlife populations, a trend that has not been counterbalanced by the existence of protected areas (Brashares et al., 2001; Fa et al., 2002).

Despite all types of hunting being forbidden in Côte d'Ivoire since 1974, the illegal bushmeat trade is widespread 


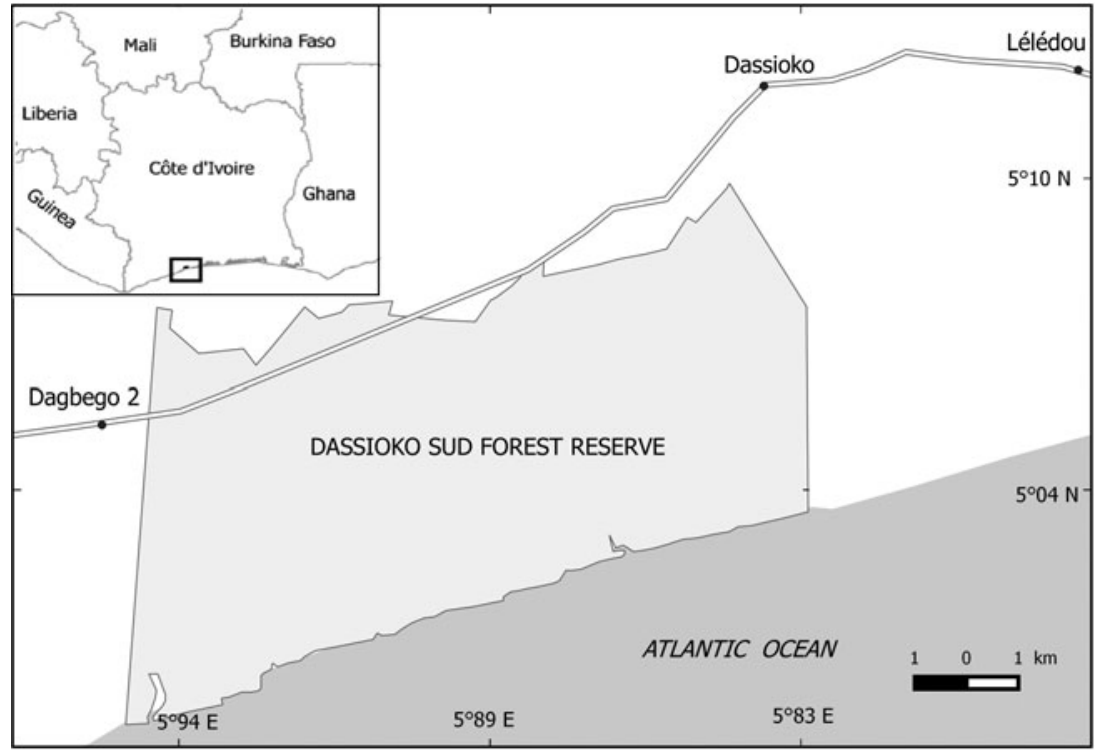

FIG. 1 The three survey sites near Dassioko Sud Forest Reserve, coastal south-eastern Côte d'Ivoire.
(Caspary et al., 2001; Gonedelé Bi et al., 2012). Caspary (1999) estimated that $120,000 \mathrm{t}$ of wild game (compared with 45,00o t of domestic meat) were consumed annually, representing a parallel economy of c. FCFA 77 billion (i.e. the equivalent of $1.7 \%$ of the country's gross domestic product). Bushmeat is particularly sought after for cultural and social purposes as well as for its taste (Caspary et al., 2001), and urban bushmeat markets have proliferated and tend to be connected with the country's main forest reserves (Caspary et al., 2001).

Although the risk of zoonotic diffusion from bushmeat activities has received a certain level of attention in Côte d'Ivoire (e.g. Liégeois et al., 2009), quantitative data on the exploitation of bushmeat by local communities are scarce and outdated. Bushmeat surveys have focused on western and northern areas (Korhogo, Taï National Park and Toumodi; Caspary et al., 2001; Bassett, 2005), and thus the bushmeat activities affecting the coastal forests are virtually unknown.

The environmental situation in coastal Côte d'Ivoire is becoming critical as almost $80 \%$ of the protected forests have been transformed into cocoa plantations (Bitty et al., 2013; Gonedelé Bi et al., 2014). The diverse Dassioko Sud Forest Reserve, a coastal evergreen forest, has been designated a wetland of international importance (Ramsar, 2005) and is home to a number of threatened species. However, a decade of political and social instability in Côte d'Ivoire has resulted in a lack of enforcement of conservation policy and a lack of efficient protection efforts. As a consequence the Reserve is now subject to considerable anthropogenic pressures, including agriculture and intense and uncontrolled hunting activities, which have led to the degradation of the forest ecosystem and the rarefaction or extirpation of several mammalian taxa (Bitty et al., 2013). We characterize and quantify the supply of bushmeat in the vicinity of the Reserve based on a 6-month survey, and attempt to answer the following questions: (1) Which species are hunted and traded around the Reserve? (2) Is the wild game hunted within or outside the Reserve? (3) What hunting techniques are used to supply the market? (4) What is the biomass of the bushmeat offtake? (5) What is the commercial income derived from the bushmeat trade around the Reserve? We discuss the contribution of our results in terms of the conservation and sustainable use of wildlife in coastal Côte d'Ivoire.

\section{Study area}

Dassioko Sud Forest Reserve (c. $80 \mathrm{~km}^{2}$; Fig. 1) is one of the last protected forest fragments of coastal Côte d'Ivoire. The climate is equatorial, characteristic of the general climate of south-western Côte d'Ivoire, with heavy rainfall and temperatures of $20-33^{\circ} \mathrm{C}$ throughout the year. The vegetation is evergreen rainforest of the Guinean forest block, which includes lowland forests from eastern Liberia to the Bandaman River in Côte d'Ivoire. The forest provides habitat for rare mammalian taxa endemic to the Upper Guinean forest ecosystem, including the Endangered white-naped mangabey Cercocebus atys lunulatus, the Critically Endangered roloway diana monkey Cercopithecus diana roloway, the Critically Endangered western chimpanzee Pan troglodytes verus, the Vulnerable forest elephant Loxodonta africana cyclotis and the Endangered Jentink's duiker Cephalophus jentinki.

\section{Methods}

\section{Bushmeat survey}

The bushmeat trade was surveyed during a 6-month period in 2012 encompassing the late dry (January-March) and 
early rainy (April-June) seasons in three villages around the Reserve: Dassioko, Dagbégo 2 and Lélédou (department of Sassandra, south-eastern Côte d'Ivoire; Fig. 1). These villages were chosen based on their proximity to the Reserve and on information that bushmeat was being sold in restaurants, which appeared to be the main trading centres for almost all the wildlife killed within the catchment area (SGB, pers. obs.).

No formal bushmeat markets exist in the study area and bushmeat is mostly sold in the local restaurants run by women. Nine restaurants (three in Dassioko, four in Dagbégo 2 and two in Lélédou) were visited during 07.00-12.00 once per week, on market days, to identify and quantify the species sold as bushmeat. All animals reported here were observed directly, identified whenever possible (not including sex) and weighed (in the case of fresh carcasses). For animals that could not be weighed directly, mean body mass information was extracted from Kingdon (1997). We asked restaurant owners the following questions: (1) What are the names of the species on sale? (2) What are the final prices of the species on sale? (3) How often per week do you have each species for sale? (4) What is the geographical origin of the hunted species? Occasionally, hunters encountered in the restaurants were asked about their hunting practices and areas. Traders were informed of the objective of the study. They participated in the survey on a voluntary basis, having indicated their willingness to reflect on the difficulties they face. Participants were assured that their identities would not be revealed.

In total we conducted interviews with 16 hunters, 10 traders, nine restaurant owners and 32 consumers from the three villages to identify the geographical origin of the bushmeat, the various hunting practices used and the number of animals hunted. SGB, $A B, A K Y$ and $A K$ visited each village with a local person and conducted interviews in the local language, using the vernacular names of the species. We gathered data on the number of animals received per day by the traders and restaurant owners, the weapons and techniques used in hunting (based on visual observation of the carcasses and/or from information gathered from the hunter whenever possible), and the final agreed market prices of bushmeat, by interviewing restaurant owners and, whenever possible, the bushmeat traders. Our data represent a minimum estimate of the volume of bushmeat in the market chain as we were working with restaurant owners, who are on the second or third levels of the chain. Trade was monitored at the level of restaurants because they were accessible, and restaurant owners were more willing than hunters to share information.

\section{Data analysis}

We recorded species' scientific names and conservation statuses following the IUCN Red List (IUCN, 2015). We collected data on numbers of species brought to the market, and pooled the data weekly. Prices of species/carcasses were calculated as the mean of daily sale prices over the study period, and were extrapolated for the whole year. Biomass for each species was calculated by multiplying the recorded number of carcasses by the mean body mass calculated from weighed individuals or from Kingdon (1997). The biomass and monetary value of the annual harvest were extrapolated from the mean number of animals killed per week. Where carcasses were cut into pieces we elicited information on the number of animals directly from the restaurant owners. When they could not give a precise answer, as a conservative estimate the processed meat was considered to represent a single individual. We estimated the number of animals sold annually at the restaurants by multiplying the number recorded per day by the weekly frequency of the market supply, then multiplying this weekly figure by 52 to extrapolate to a whole year.

Statistical analyses were carried out using SPSS v. 17.0 (SPSS Inc., Chicago, USA). We used multiple regression analysis to identify combinations of variables (proportion of animals killed, mean body mass, total biomass, cost of carcass, cost per body mass, hunting practices used) that influenced poaching pressure. These variables were log transformed as needed to improve normality. For the second set of regression the response variable was number of animals sold. Covariates investigated included the number of residents in the village and the distance between the village and the Reserve. The Spearman rank correlation coefficient (two tails) was used to test correlation trends between the hunting practices used and the body mass of hunted species. The numbers of carcasses observed in the dry season and the rainy season were compared using $F$ statistics.

\section{Results}

\section{Species hunted around Dassioko Sud Forest Reserve}

During the 24 weeks of the survey a total of 376 mammals (98\%) and eight reptiles ( $2 \%$ ) were received in the nine restaurants surveyed (Table 1 ). We recorded a total of 19 species (14 animals could not be identified to the species level because they were smoked or cut into pieces), which were classified into eight main taxonomic groups: Artiodactyla $(\mathrm{n}=3$ species), Carnivora $(n=3)$, Pholidota $(n=2)$, Hyracoidea $(n=1)$, primates $(n=3)$, Rodentia $(n=5)$, Squamata $(n=1)$ and Crocodilia $(n=1)$. Rodentia was the most frequently sold taxon by number of individuals (64\%), followed by primates (11\%), and Artiodactyla (10\%) and Carnivora (10\%) (Fig. 2).

Giant pouched rats Cricetomys sp. (38\%), the marsh cane rat Thryonomys swinderianus (16\%), Maxwell's duiker Philantomba maxwelli (6\%) and the brush-tailed porcupine 
TABLE 1 Details of the species sold in restaurants in the villages of Dassioko, Dagbégo 2 and Lélédou, in the vicinity of the Dassioko Sud Forest Reserve, Côte d'Ivoire (Fig. 1), with numbers sold in each village, total number (and percentage), mean biomass, total biomass, mean price, and mean price per $\mathrm{kg}$.

\begin{tabular}{|c|c|c|c|c|c|c|c|c|}
\hline \multirow[b]{2}{*}{ Species } & \multicolumn{3}{|c|}{ Number of individuals sold } & \multirow{2}{*}{$\begin{array}{l}\text { Total no. } \\
\text { sold }(\%)\end{array}$} & \multirow{2}{*}{$\begin{array}{l}\text { Mean } \\
\text { biomass } \\
(\mathrm{kg})\end{array}$} & \multirow{2}{*}{$\begin{array}{l}\text { Total } \\
\text { biomass } \\
(\mathrm{kg})\end{array}$} & \multirow[b]{2}{*}{ Mean price $\pm S D$, FCFA (USD) } & \multirow{2}{*}{$\begin{array}{l}\text { Mean } \\
\text { price per } \\
\mathrm{kg} \\
(\mathrm{FCFA})\end{array}$} \\
\hline & Dassioko & Dagbégo 2 & Lélédou & & & & & \\
\hline $\begin{array}{l}\text { Marsh cane rat } \\
\text { Thryonomys } \\
\text { swinderianus }\end{array}$ & 26 & 19 & 14 & $59(15.69)$ & 6.08 & 358.72 & $7,305.56 \pm 2,383.39(14.31 \pm 4.67)$ & $1,201.57$ \\
\hline $\begin{array}{l}\text { Maxwell's duiker } \\
\text { Philantomba } \\
\text { maxwellii }\end{array}$ & 12 & 8 & 4 & $24(6.38)$ & 10.00 & 240.00 & $13,269.23 \pm 2,962.37(25.99 \pm 5.80)$ & $1,326.92$ \\
\hline $\begin{array}{l}\text { Bay duiker } \\
\text { Cephalophus } \\
\text { dorsalis }\end{array}$ & 3 & 0 & 1 & $4(1.06)$ & 20.00 & 80.00 & $18,500 \pm 707.11(36.24 \pm 1.39)$ & 700.00 \\
\hline Genets Genetta sp & 7 & 6 & 3 & $16(4.26)$ & 2.00 & 32.00 & $3,500 \pm 1,414.21(6.86 \pm 2.77)$ & $1,750.00$ \\
\hline $\begin{array}{l}\text { African civet } \\
\text { Civettictis civetta }\end{array}$ & 2 & 2 & 1 & $5(1.33)$ & 20.00 & 100.00 & $5,700 \pm 570.09(11.17 \pm 1.12)$ & 285.00 \\
\hline $\begin{array}{l}\text { West African } \\
\text { dwarf crocodile } \\
\text { Osteolaemus } \\
\text { tetraspis }\end{array}$ & 2 & 0 & 0 & $2(0.53)$ & 40.00 & 80.00 & $6,250 \pm 353.55(12.24 \pm 0.69)$ & 156.25 \\
\hline $\begin{array}{l}\text { Squirrels } \\
\text { (Sciuridae) }\end{array}$ & 1 & 0 & 0 & $1(0.27)$ & 0.75 & 0.75 & $1,250 \pm 353.55(2.45 \pm 0.69)$ & $1,666.67$ \\
\hline $\begin{array}{l}\text { Squirrels } \\
\text { Anomalurus sp. }\end{array}$ & 5 & 3 & 3 & $11(2.93)$ & 1.80 & 19.80 & $3,812.5 \pm 923.41(7.47 \pm 1.81)$ & $2,118.06$ \\
\hline $\begin{array}{l}\text { Bushbuck } \\
\text { Tragelaphus } \\
\text { scriptus }\end{array}$ & 3 & 4 & 2 & $9(2.39)$ & 71.25 & 641.25 & $19,200 \pm 1,303.84(37.62 \pm 2.55)$ & 269.47 \\
\hline $\begin{array}{l}\text { Brush-tailed por- } \\
\text { cupine Atherurus } \\
\text { africanus }\end{array}$ & 9 & 8 & 6 & $23(6.12)$ & 4.00 & 92.00 & $8,272.73 \pm 1,992.03(16.21 \pm 3.90)$ & $2,068.18$ \\
\hline $\begin{array}{l}\text { Cusimanse mon- } \\
\text { goose Crossarchus } \\
\text { obscurus }\end{array}$ & 7 & 9 & 2 & $18(4.79)$ & 0.85 & 15.30 & $2,630 \pm 731.89(5.15 \pm 1.43)$ & $3,094.12$ \\
\hline $\begin{array}{l}\text { Campbell's mon- } \\
\text { key Cercopithecus } \\
\text { campbelli }\end{array}$ & 3 & 3 & 4 & $10(2.66)$ & 5.80 & 58.00 & $5,500 \pm 707.11(10.78 \pm 1.39)$ & 948.28 \\
\hline $\begin{array}{l}\text { Pangolins } \\
\text { (Manidae) }\end{array}$ & 2 & 1 & 1 & $4(1.06)$ & 3.00 & 12.00 & $4,333.33 \pm 288.68(8.49 \pm 0.57)$ & $1,444.44$ \\
\hline $\begin{array}{l}\text { Tree pangolin } \\
\text { Phataginus } \\
\text { tricuspis }\end{array}$ & 0 & 0 & $: 0$ & $2(0.53)$ & 3.00 & 3.00 & $5,000 \pm 0.00(9.80 \pm 0.00)$ & $1,666.67$ \\
\hline $\begin{array}{l}\text { Long-tailed pan- } \\
\text { golin Uromanis } \\
\text { tetradactyla }\end{array}$ & 1 & 0 & 0 & $1(0.27)$ & 3.00 & 3.00 & $5,000 \pm 0.00(9.80 \pm 0.00)$ & $1,666.67$ \\
\hline $\begin{array}{l}\text { Lesser spot-nosed } \\
\text { monkey } \\
\text { Cercopithecus } \\
\text { petaurista }\end{array}$ & 1 & 2 & 1 & $4(1.06)$ & 6.20 & 24.80 & $5,500 \pm 408.25(10.78 \pm 0.80)$ & 887.10 \\
\hline $\begin{array}{l}\text { Bosman's potto } \\
\text { Perodicticus potto }\end{array}$ & 8 & 7 & 7 & $22(5.85)$ & 1.60 & 35.20 & $2,958.33 \pm 257.46(5.80 \pm 0.50)$ & $1,848.96$ \\
\hline Python Python sp. & 2 & 0 & 0 & $2(0.53)$ & 55.00 & 110.00 & $6,500 \pm 707.11(12.73 \pm 1.39)$ & 118.18 \\
\hline $\begin{array}{l}\text { Giant pouched rat } \\
\text { Cricetomys } \\
\text { gambianus }\end{array}$ & 49 & 59 & 37 & $145(38.56)$ & 1.40 & 203.00 & $1,761.95 \pm 449.07(3.45 \pm 0.88)$ & $1,258.54$ \\
\hline $\begin{array}{l}\text { Striped ground } \\
\text { squirrel Euxerus } \\
\text { erythropus }\end{array}$ & 2 & 1 & 0 & $3(0.80)$ & 1.00 & 3.00 & $900 \pm 141.42(1.76 \pm 0.28)$ & 900 \\
\hline
\end{tabular}


Table 1 (Cont.)

\begin{tabular}{|c|c|c|c|c|c|c|c|c|}
\hline \multirow[b]{2}{*}{ Species } & \multicolumn{3}{|c|}{ Number of individuals sold } & \multirow{2}{*}{$\begin{array}{l}\text { Total no. } \\
\text { sold (\%) }\end{array}$} & \multirow{2}{*}{$\begin{array}{l}\text { Mean } \\
\text { biomass } \\
(\mathrm{kg})\end{array}$} & \multirow{2}{*}{$\begin{array}{l}\text { Total } \\
\text { biomass } \\
(\mathrm{kg})\end{array}$} & \multirow[b]{2}{*}{ Mean price $\pm S D$, FCFA (USD) } & \multirow{2}{*}{$\begin{array}{l}\text { Mean } \\
\text { price per } \\
\mathrm{kg} \\
\text { (FCFA) }\end{array}$} \\
\hline & Dassioko & Dagbégo 2 & Lélédou & & & & & \\
\hline $\begin{array}{l}\text { Cercopithecine } \\
\text { monkey }\end{array}$ & 7 & 0 & 0 & $7(1.86)$ & 5.80 & 40.60 & $6,916.67 \pm 2,245.37(13.55 \pm 4.40)$ & $1,192.53$ \\
\hline $\begin{array}{l}\text { Cercopithecus sp. } \\
\text { Nile monitor } \\
\text { Varanus niloticus }\end{array}$ & 2 & 1 & 1 & $4(1.06)$ & 6.00 & 24.00 & $5,000 \pm 816.50(9.79 \pm 1.60)$ & 833.33 \\
\hline $\begin{array}{l}\text { Tree hyrax } \\
\text { Dendrohyrax } \\
\text { dorsalis }\end{array}$ & 2 & 0 & 0 & $2(0.53)$ & 2.70 & 5.40 & $4,250 \pm 353.55(8.32 \pm 0.69)$ & $1,574.07$ \\
\hline Total & 156 & 133 & 87 & $376(100)$ & & $2,178.82$ & & \\
\hline
\end{tabular}

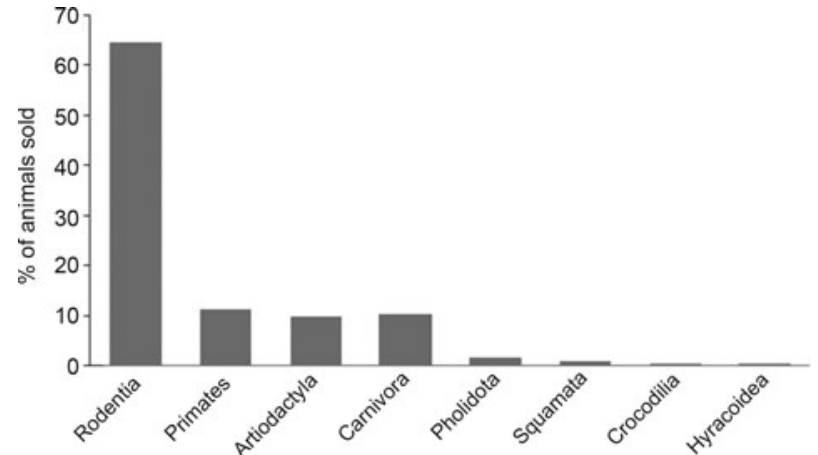

FIG. 2 Percentage of taxonomic groups found in nine restaurants around the Dassioko Sud Forest Reserve (Fig. 1).

Atherurus africanus (6\%) were the most harvested species, representing more than half of the entire offtake (66\%). Of the 19 species identified, three are of conservation concern, categorized as Vulnerable on the IUCN Red List: the tree pangolin Phataginus tricuspis, the long-tailed pangolin Uromanis tetradactyla and the West African dwarf crocodile Osteoleamus tetraspis. No more than two individuals of each of these species were sold during the survey period.

\section{Geographical origin of bushmeat, and hunting techniques used}

Based on interviews with bushmeat stakeholders we estimate that a greater percentage of the animals $(54 \%)$ were killed in the Reserve than on nearby farms (36\%) or fallows (i.e. non-cultivated old farms; $10 \%$ ).

Based on the direct count of carcasses observed, a mean of $125.33 \pm$ SD 35.15 animals per village (range 87-156) was recorded during the study period. No significant differences were detected among the mean numbers of animals captured per village $(F=0.62, \mathrm{df}=42.39, \mathrm{P}=0.541)$. A marginally significant correlation was detected between offtake (number of animals captured in each village) and village size $(r=0.97, \mathrm{n}=3, \mathrm{P}=0.091)$. There was no significant correlation between the distance separating the villages from the Reserve and the number of animals captured in each village $(r=-0.78, \mathrm{n}=3, \mathrm{P}=0.43)$. The number of carcasses in the dry season was not significantly different from that in the rainy season $(F=2.281, \mathrm{P}>0.05)$.

Local hunters used four techniques to kill animals: snares $(65 \%)$, machetes $(7 \%)$ and wood sticks ( $1 \%)$, which are traditional hunting techniques, as well as guns $(27 \%)$. The use of guns was not correlated with the mean body mass of the target species $(r=0.066, \mathrm{P}=0.769)$, nor was the use of snares $(r=0.152, \mathrm{P}=0.525)$.

\section{Bushmeat offtake and commercial income}

The total weight of bushmeat sold in the restaurants during the survey was $2,179 \mathrm{~kg}$, with the highest proportion (44\% of total weight) representing artiodactyls, followed by rodents ( $677 \mathrm{~kg} ; 31 \%)$. In terms of species the bushbuck Tragelaphus scriptus contributed the highest proportion by weight (641 $\mathrm{kg} ; 29 \%$ of total weight), followed by the marsh cane rat (241 kg; 16.5\%), Maxwell's duiker Philantomba maxwelli $(240 \mathrm{~kg} ; 11 \%)$ and the giant pouched rat $(203 \mathrm{~kg} ; 9 \%)$ (Table 1).

The bushbuck had the highest price per carcass (FCFA $19,200 \pm$ SD 1,304, USD 37.6), followed by the bay duiker Cephalophus dorsalis (FCFA 18,500 \pm 707 , USD 36). The least expensive species was the striped ground squirrel Euxerus erythropus (FCFA $900 \pm 141$, USD 1.80). In general the most commonly hunted species were among those sold at the highest prices per body mass.

The proportion of animals sold around the Reserve was significantly, negatively correlated with body mass $(r=-$ 0.96, $\mathrm{P}=0.003$ ). Furthermore, prices divided by body mass were significantly negatively correlated with mean body mass $(r=-0.98, \mathrm{P}=0.000)$, with larger species having a lower price per $\mathrm{kg}$ than smaller species (Fig. 3); for example, the bushbuck had one of the lowest prices (FCFA 


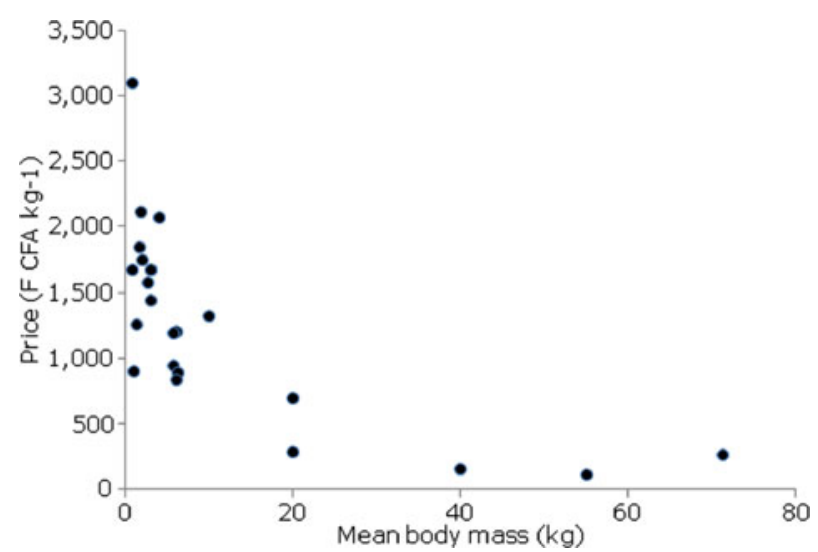

FIG. 3 Correlation between mean body mass and price per $\mathrm{kg}$ for the various species sold as bushmeat in restaurants near Dassioko Sud Forest Reserve (Fig. 1). Values for mean body mass were extracted from Kingdon (1997) and from our own survey.

$\left.269.5 \mathrm{~kg}^{-1}\right)$. Conversely, most of the smaller species approached or exceeded the mean price per kg (FCFA 1,260, USD 2.5; Supplementary Table $\mathrm{S}_{1}$ ); for instance, the cusimanse mongoose Crossarchus obscurus had the highest price per $\mathrm{kg}$ (FCFA 3,094, USD 5) and is among the species with the lowest mean body mass $(0.85 \mathrm{~kg})$.

The estimated total number of animals sold at the restaurants around the Reserve was c. 5,518.50 during 6 months. Extrapolated to 1 year this is c. 11,886 with a total biomass of $40,428.03 \mathrm{~kg}$ and an annual monetary value of FCFA c. $47,728,516$ (USD 93,485.75) for the bushmeat traders in the three villages (Table 1). Given our estimate of the proportions of animals killed within the Reserve $(53 \%)$ we speculate that a minimum of 6,300 animals, representing a biomass of $21,426.86 \mathrm{~kg}$, are extirpated annually from the protected area.

\section{Discussion}

\section{Species composition and geographical origin of} bushmeat

Our 6-month survey revealed that rodents comprised the highest proportion of mammals sold in restaurants in villages around Dassioko Sud Forest Reserve. Small prey (including giant pouched rats, marsh cane rats, Maxwell's duikers and brush-tailed porcupines) were the primary targets of poachers in the region, in contrast with other parts of tropical Africa, where hunters target large or medium-sized prey (FitzGibbon, 1998; Fa \& Peres, 2001). Although this finding may be biased by the fact that we surveyed restaurants, which are at the end of the bushmeat trade chain, our results are similar to previous findings in the region of Toumodi, central Côte d'Ivoire (Caspary, 1999), and Liberia (Anstey, 1991; Béné et al., 2013). A higher proportion of carcasses of small vs medium-sized species was also recorded in the Takoradi market in Ghana (Cowlishaw et al., 2005).
Our findings indicate that small mammalian prey is characteristic of the bushmeat sold in restaurants around the Reserve, although large prey species are generally more profitable to hunters (Peres, 1990; Fa et al., 2000). In line with reports of faunal decline within the coastal and other forests of Côte d'Ivoire (Gonedelé Bi et al., 2012; Bitty et al., 2013), similar declines in the availability of large and medium-sized mammals for sale on bushmeat stalls have been reported in tropical Africa (Fa \& Garcia Yuste, 2001; Ohl-Schacherer et al., 2007). Such declines are not necessarily attributable to hunter preference for larger mammals, as vulnerable taxa such as habitat-specialized, larger mammals with $\mathrm{K}$ reproductive strategies can be depleted rapidly in hunting areas (Cowlishaw et al., 2005). In contrast, ecologically versatile, smaller mammals (e.g. rodents and small antelopes; Happold, 1987) with $\mathrm{r}$ reproductive strategies may persist in heavily hunted areas and agricultural landscapes (Kümpel et al., 2010). Thus, the species composition of the bushmeat sold in restaurants around the Reserve probably reflects the cumulative effects of habitat degradation and hunting pressure on mammals in the area. There has been rapid forest degradation in the Reserve as a result of lack of enforcement of conservation policy, following a decade of political and social instability exacerbated by the 2010 electoral crisis (Bitty et al., 2013; SGB, pers. obs.).

Our results indicate that the majority $(53 \%)$ of the bushmeat found in the local restaurants originated in the Reserve, where there is increased poaching pressure, persistent lack of management, and increased accessibility to the forested area. Our analyses showed that poaching pressure is not correlated to the geographical location of the village, contrary to the conclusions of several other studies in tropical Africa (Muchaal \& Ngandjui, 1999; Fa \& Garcia Yuste, 2001; McNamara et al., 2015). The Reserve is the only remaining forest fragment in the south-eastern coastal region of Côte d'Ivoire and may therefore constitute the last source of wild game in the area, and rural communities are heavily dependent on natural resources, including bushmeat (SGB, pers. obs.). As hunting activity is not dependent on the distance between villages and the Reserve borders, all householders are potential harvesters of faunal resources within the Reserve.

There was a marginal correlation between the numbers of animals sold in the markets and the size of the villages involved in the bushmeat trade. This indicates a possible influence of the level of demand (village size) on the volume of bushmeat consumed (Robinson \& Bennett, 2000; Fa et al., 2015). A significant proportion of the landscape around the Reserve is used for agriculture and settlement. As human population density increases near protected areas, more land is needed for livelihood maintenance (Wittemyer et al., 2008). This has increased hunting pressure on the Reserve, as confirmed by hunters who reported that capturing animals was easier inside than outside the Reserve (SGB, pers. obs.). 
Our survey did not indicate seasonal variation in the bushmeat offtake and we are aware that simply multiplying a 6-month study by two to obtain an annual estimate may overlook temporal or seasonal variations. Hunting may depend on the seasonal availability of, or preference for, alternative livelihoods (Kümpel, 2006); for example, it can be an important fall-back livelihood during the agricultural lean season or in periods of crisis (de Merode et al., 2004).

\section{Sustainable use of wild game?}

Rodents and ungulates together represented $74 \%$ of the carcasses sold in the bushmeat restaurants around the Reserve. These taxa have been reported as having a similar magnitude of importance in other regions of Côte d'Ivoire (Caspary et al., 2001) and West Africa ( $78 \%$ in the Republic of Guinea, Brugière \& Magassouba, 2009; 67\% in Ghana, Ntiamoa-Baidu, 1998; 79\% in Nigeria, Fa et al., 2006, Okiwelu et al., 2009; $78 \%$ in Liberia, Béné et al., 2013), and in Central Africa ( $71 \%$ in Cameroon, Fa \& Brown, 2009; $68-78 \%$ in Kisangani, Democratic Republic of the Congo, van Vliet et al., 2012). At the species level our data showed that the bushbuck and the marsh cane rat contributed the highest proportion of the total biomass of bushmeat sold in restaurants, which is probably attributable to the conversion of forest habitat into farmland. Surveys of bushmeat markets in West Africa have confirmed that both species are among the top five species sold, in terms of biomass (Ntiamoa-Baidu, 1998; Béné et al., 2013), supporting the view that restaurant sales are a usable proxy for the spectrum of bushmeat items sold in markets.

Our conservative estimate of annual harvest of bushmeat around the Reserve represented a total biomass of c. $40,428.03 \mathrm{~kg}$ (c. 11,886 animals) and an annual monetary value of c. FCFA 47,728,516 (c. USD 93,485.75), as derived from the nine restaurants surveyed (Supplementary Table S1). This yields an annual income of USD c. 10,387.31 per person, exceeding more than tenfold the mean annual income of cocoa farmers (c. FCFA 466,032, c. USD 932; Gnamian, 2008). Thus, the sale of bushmeat in restaurants appears to be a highly profitable activity compared to cocoa farming, which is one of the most important agricultural activities and sources of revenue in Côte d'Ivoire.

Given our estimate of the proportions of animals killed inside the Reserve $(53 \%)$ we speculate that a minimum of 6,300 animals, representing a biomass of $21,426.86 \mathrm{~kg}$, are extirpated annually from the protected area to supply the nine restaurants in the three villages. These estimates are greater than the annual offtake of 4,982 animals reported by Béné et al. (2013) in the nearby Nimba region in Liberia based on direct monitoring of the hunting activity in five localities. As we limited our survey to restaurants, our estimates are probably underestimates. Hunters are key stakeholders in the bushmeat commodity chain, selling their products to the highest bidder; further investigations around the Reserve should target this group.

We estimate that the mean value of bushmeat sold in the surveyed restaurants was USD $2.52 \mathrm{~kg}^{-1}$, similar to the estimate of USD 1.5-2.5 kg-1 for the rural markets of Cameroon and Nigeria (Macdonald et al., 2012). Our estimates greatly exceed the prices reported for conservancy areas in Eastern Africa (USD 1.33 in Zimbabwe, 0.93 in Malawi, 0.75 in Kenya; Ndibalema \& Songorwa, 2008), suggesting that demands and practices in the bushmeat trade may not be equivalent in the rainforest and savannah zones. Prices per $\mathrm{kg}$ of hunted species were significantly negatively correlated to mean body mass, in contrast with findings in rural markets in Cameroon (Macdonald et al., 2012). This may be partly explained by the fact that bushmeat is sold per individual rather than per $\mathrm{kg}$ around the Reserve. Thus, the metric link between the animal and its monetary value may not be fully understood by the stakeholders operating in the bushmeat chain.

It would be premature to draw conclusions about the sustainability of the bushmeat trade occurring around the Reserve, particularly as the prevalence of $r$ strategists such as rodents and small antelopes in restaurants is not necessarily an indicator of sustainability. Moreover, there is evidence from this study and other surveys that several medium-to-large species (e.g. the diana monkey, the king colobus Colobus polykomos, the western red colobus Piliocolobus badius, Jentink's duiker, the giant pangolin Manis gigantea, and the leopard Panthera pardus) have already been extirpated from the Reserve (Gonedelé Bi et al., 2014). However, most of the species found in restaurants were not of conservation concern, except for the Vulnerable tree and long-tailed pangolins and West African dwarf crocodile. Similar results were found in south-eastern Côte d'Ivoire (Caspary et al., 2001). This does not necessarily mean that hunters distinguish between species on the basis of their conservation status; rather, the most plausible explanation is the rarity of these species in the area, the market generally reflecting the current status of the fauna that it continues to deplete (Olayemi et al., 2011).

The use of cable snares as the dominant hunting technique $(65 \%)$ in the vicinity of the Reserve hampers any attempts at sustainable hunting (Robinson \& Bennett, 2004). Cable snares are probably the most widely used hunting method among African forest hunters (Noss, 1998, 2000), being affordable, easy to implement and effective compared to hunting with guns (Noss, 1998), but non-selective. Although most West African countries have officially banned the use of cable snares (Fa \& Garcia Yuste, 2001), hunters continue to use them, and they have not been banned in Côte d'Ivoire. 


\section{Conclusions}

Traditional communities depend on wildlife as a source of food and income. Our survey of the restaurants around Dassioko Sud Forest Reserve identified an intense and regular bushmeat trade affecting a wide spectrum of mammals. It is likely that future studies monitoring hunter activities directly would yield a finer estimate of the poaching pressure in the area. The lack of effective protection exposes the Reserve to multiple illegal activities, including hunting, forest encroachment and illegal settlement and farming, a situation exacerbated by the political crisis in 2010. The increasing demand for bushmeat from large urban markets has also created incentives for the illegal commercial exploitation of the Reserve, which is not under appropriate management. Thus, we consider that there is a need to develop projects to improve people's knowledge about wildlife conservation in the area. We passed our conclusions based on this survey to the local authority in charge of the surveillance of Dassioko Sud Forest Reserve and to the Ivorian authorities responsible for Parks and Reserves, in 2013, but received no response. However, since the Ebola outbreak in West Africa in 2014 prohibition measures in relation to hunting and bushmeat sales have been reinforced in Côte d'Ivoire and may have temporarily slowed down activities related to the bushmeat trade.

\section{Acknowledgements}

This research was funded by the International Foundation for Science, grant number D-5050. We thank the Minister of Scientific Research of Côte d'Ivoire for the research permit, the Swiss Centre for Scientific Research for logistical support, the Forest Development Authority and the Ivorian Office of Parks and Reserves for the permit to access the protected area, and the local communities around the surveyed forests, and the field guides, for their assistance. We acknowledge the editor and anonymous reviewers for providing valuable comments.

\section{References}

Anstey, S. (1991) Wildlife Utilization in Liberia. WWF/FDA wildlife survey report to WWF International, Gland, Switzerland.

B ASSETt, T.J. (2005) Card-carrying hunters, rural poverty, and wildlife decline in northern Côte d'Ivoire. The Geographical Journal, 171, 24-35.

Béné, J.-C.K., Gamys, J. \& Dufour, S. (2013) The hunting practice in northern Nimba County, Liberia. Global Advanced Research Journal of Environmental Science and Toxicology, 2, 22-36.

Bennett, E.L. \& Robinson, J.G. (2000) Hunting of Wildlife in Tropical Forests: Implications for Biodiversity and Forest Peoples. Global Environment Division, The World Bank, Washington, DC, USA.
Bitty, E.A., Gonedelé Bi, S. \& McGraw, W.S. (2013) Accelerating deforestation and hunting in protected reserves jeopardize primates in southern Côte d'Ivoire. American Journal of Physical Anthropology, 150, 9.

Brashares, J.S., ArCeSe, P. \& Sam, M.K. (2001) Human demography and reserve size predict wildlife extinction in West Africa. Proceedings of the Royal Society of London. Series B: Biological Sciences, 268, 2473-2478.

Brugière, D. \& Magassouba, B. (2009) Pattern and sustainability of the bushmeat trade in the Haut Niger National Park, Republic of Guinea. African Journal of Ecology, 47, 630-639.

CAspary, H.-U. (1999) Utilisation de la faune sauvage en Côte d'Ivoire et en Afrique de l'Ouest: potentiels et contraintes pour la coopération au développement. GTZ, Eschborn, Germany.

Caspary, H.-U., Koné, I., Prouot, C. \& De Paw, M. (2001) La chasse et la filière viande de brousse dans l'espace Tä̈, Côte d'Ivoire. Tropenbos, Wageningen, The Netherlands.

Cowlishaw, G., Mendelson, S. \& Rowcliffe, J.M. (2005) Evidence for post-depletion sustainability in a mature bushmeat market. Journal of Applied Ecology, 42, 460-468.

de Merode, E., Homewood, K. \& Cowlishaw, G. (2004) The value of bushmeat and other wild foods to rural households living in extreme poverty in Democratic Republic of Congo. Biological Conservation, 118, 573-581.

Edderai, D. \& Dame, M. (2006) A census of the commercial bushmeat market in Yaoundé, Cameroon. Oryx, 40, 472-475.

FA, J.E. \& Brown, D. (2009) Impacts of hunting on mammals in African tropical moist forests: a review and synthesis. Mammal Review, 39, 231-264.

Fa, J.E., Currie, D. \& Meeunig, J. (2003) Bushmeat and food security in the Congo Basin: linkages between wildlife and people's future. Environmental Conservation, 30, 71-78.

Fa, J.E. \& Garcia Yuste, J.E. (2001) Commercial bushmeat hunting in the Monte Mitra forests, Equatorial Guinea: extent and impact. Animal Biodiversity \& Conservation, 24, 31-52.

Fa, J.E., Garcia Yuste, J.E. \& Castelo, R. (2000) Bushmeat markets on Bioko Island as a measure of hunting pressure. Conservation Biology, 14, 1602-1613.

Fa, J.E., Olivero, J., Farfán, M.Á., Márquez, A.L., Duarte, J., NACKoney, J. et al. (2015) Correlates of bushmeat in markets and depletion of wildlife. Conservation Biology, 29, 805-815.

Fa, J.E., Olivero, J., Farfán, M.Á., Márquez, A.L., Vargas, J.M., REAL, R. \& NASI, R. (2014) Integrating sustainable hunting in biodiversity protection in Central Africa: hot spots, weak spots, and strong spots. PLoS ONE, 9(11), e112367.

FA, J.E. \& Peres, C.A. (2001) Game vertebrate extraction in African and Neotropical forests: an intercontinental comparison. In Conservation of Exploited Species (eds J.D. Reynolds, G.M. Mace, K.H. Redford \& J.G. Robinson), pp. 203-241. Cambridge University Press, Cambridge, UK.

FA, J.E., Peres, C.A. \& Meeuwig, J. (2002) Bushmeat exploitation in tropical forests: an intercontinental comparison. Conservation Biology, 16, 232-237.

Fa, J.E., Seymour, S., Dupain, J., Amin, R., Albrechtsen, L. \& MACDONALD, D. (2006) Getting to grips with the magnitude of exploitation: bushmeat in the Cross-Sanaga rivers region, Nigeria and Cameroon. Biological Conservation, 129, 497-510.

FitzGibвоN, C. (1998) The management of subsistence harvesting: behavioral ecology of hunters and their mammalian prey. In Behavioral Ecology and Conservation Biology (ed. T. Caro), pp. 449473. Oxford University Press, Oxford, UK.

Gnamian, A.P.E. (2008) Libéralisation et pauvreté: le cas des producteurs de cacao de la Côted'Ivoire. Mémoire de Maîtrise. Université du Québec, Montréal, Canada. 
Gonedelé Bi, S., Bitty, A., Ouatara, K. \& McGraw, W.S. (2014) Primate surveys in Côte d'Ivoire's SassandraBandama interfluvial region with notes on a remnant population of black-and-white colobus. African Journal of Ecology, 52, 491-498.

Gonedelé Bi, S., Koné, I., Bitty, A.E., Béné, J.C., Akpatou, B. \& Zinner, D. (2012) Distribution and conservation status of catarrhine primates in Côte d'Ivoire (West Africa). Folia Primatologica, 83, 11-23.

HARRISOn, R.D. (2011) Emptying the forest: hunting and the extirpation of wildlife from tropical nature reserves. BioScience, 61, 919-924.

Happold, D.C.D. (1987) The Mammals of Nigeria. Oxford University Press, New York, USA.

IUCN (2015) The IUCN Red List of Threatened Species v. 2014.3. Http:// www.iucnredlist.org [accessed 25 September 2015].

Jenkins, R.K.B., Keane, A., Rakotoarivelo, A.R., Rakotomboavonjy, V., Randrianandrianina, F.H., Razafimanahaka, H.J. et al. (2011) Analysis of patterns of bushmeat consumption reveals extensive exploitation of protected species in eastern Madagascar. PLoS ONE, 6(12), e27570.

Kingdon, J. (1997) The Kingdon Field Guide to African Mammals. Academic Press, London, UK.

KÜMPEL, N.F. (2006) Incentives for sustainable hunting of bushmeat in Rio Muni. PhD thesis. Imperial College London, UK.

Kümpel, N.F., Milner-Gulland, E.J., Cowlishaw, G. \& RowCliffe, J.M. (2010) Assessing sustainability at multiple scales in a rotational bushmeat hunting system. Conservation Biology, 24, 861-871.

Liégeois, F., Lafay, B., Formenty, P., Locatelli, S., Courgnaud, V., Delaporte, E. \& Peeters, M. (2009) Full-length genome characterization of a novel simian immunodeficiency virus lineage (SIVolc) from olive colobus (Procolobus verus) and new SIVwrcPbb strains from western red colobus (Piliocolobus badius badius) from the Taï forest in Ivory Coast. Journal of Virology, 83, 428-439.

Macdonald, D.W., Johnson, P.J., Albrechtsen, L., Seymour, S., Dupain, J., Hall, A. \& FA, J.E. (2012) Bushmeat trade in the CrossSanaga rivers region: evidence for the importance of protected areas. Biological Conservation, 147, 107-114.

Mbete, R.A., Banga-Mboko, H., Racey, P., Mfoukou-Ntsakala, A., NGanga, I., Vermeulen, C. et al. (2011) Household bushmeat consumption in Brazzaville, the Republic of the Congo. Tropical Conservation Science, 4, 187-202.

McNamara, J., Kusimi, J.M., Rowcliffe, J.M., Cowlishaw, G., Brenyah, A. \& Milner-Gulland, E.J. (2015) Long-term spatio-temporal changes in a West African bushmeat trade system. Conservation Biology, 29, 1446-1457.

Milner-Gulland, E.J. \& Bennett, E.L. (2003) Wild meat: the bigger picture. Trends in Ecology \& Evolution, 18, 351-357.

MuchaAl, P.K. \& NGAndJui, G. (1999) Impact of village hunting on wildlife populations in the western Dja Reserve, Cameroon. Conservation Biology, 13, 385-396.

Nasi, R., Brown, D., Wilkie, D., Bennett, E., Tutin, C., van Tol, G. \& Christophersen, T. (2008) Conservation and Use of Wildlife-based Resources: The Bushmeat Crisis. Technical Series no. 33. Secretariat of the Convention on Biological Diversity, Montreal, Canada \& Center for International Forestry Research (CIFOR), Bogor, Indonesia.

Ndibalema, V.G. \& Songorwa, A.N. (2008) Illegal meat hunting in Serengeti: dynamics in consumption and preferences. African Journal of Ecology, 46, 311-319.

Norris, K., Asase, A., Collen, B., Gockowksi, J., Mason, J., PhalAN, B. \& WADE, A. (2010) Biodiversity in a forest-agriculture mosaic-the changing face of West African rainforests. Biological Conservation, 143, 2341-2350.

Noss, A.J. (1998) The impacts of cable snare hunting on wildlife populations in the forests of the Central African Republic. Conservation Biology, 12, 390-398.

Noss, A.J. (200o) Cable snares and nets in the Central African Republic. In Hunting for Sustainability in Tropical Forests (eds J. G. Robinson \& E.L. Bennett), pp. 282-304. Columbia University Press, New York, USA.

Ntiamoa-Baidu, Y. (1998) Wildlife Development Plan 1998-2003. Volume 6: Sustainable Harvesting, Production and Use of Bushmeat. Protected Areas Management and Wildlife Conservation Project, Wildlife Department, Accra, Ghana.

Oates, J.F., Abedi-Lartey, M., McGraw, W.S., Struhsaker, T.T. \& Whilesides, G.H. (2000) Extinction of a West African red colobus monkey. Conservation Biology, 14, 1526-1532.

Ohl-Schacherer, J., Shepard, Jr, G.H., Kaplan, H., Peres, C.A., LEVI, T. \& YU, D.W. (2007) The sustainability of subsistence hunting by Matsigenka native communities in Manu National Park, Peru. Conservation Biology, 21, 1174-1185.

Okiwelu, S.N., Ewurum, N. \& Noutcha, M.A.E. (2009) Wildlife harvesting and bushmeat trade in Rivers State, Nigeria: I. Species composition, seasonal abundance and cost. Scientia Africana, 8, 1-8.

Olayemi, A., Oyeyiola, A., Antunes, A., Bonillo, C., Cruaud, C. \& GAUBERT, P. (2011) Contribution of DNA-typing to bushmeat surveys: assessment of a roadside market in south-western Nigeria. Wildlife Research, 38, 696-716.

Peres, C.A. (1990) Effects of hunting on western Amazonian primate communities. Biological Conservation, 54, 47-59.

RAMSAR (2005) The Annotated Ramsar List: Côte d'Ivoire. Http:// ramsar.rgis.ch/cda/en/ramsar-pubs-notes-anno-cote/main/ramsar/ 1-30-168\%5E16466_400o_o [accessed 11 February 2016].

Robinson, J.G. \& Bennett, E.L. (2004) Having your wildlife and eating it too: an analysis of hunting sustainability across tropical ecosystems. Animal Conservation, 7, 397-408.

Robinson, J.G. \& Bennett, E.L. (2002) Will alleviating poverty solve the bushmeat crisis? Oryx, 36, 332.

Robinson, J.G. \& Bennett, E.L. (eds) (200o) Hunting for Sustainability in Tropical Forests. Columbia University Press, New York, USA.

van Vliet, N., Nebesse, C., Gambalemoke, S., Akaibe, D. \& Nasi, R. (2012) The bushmeat market in Kisangani, Democratic Republic of Congo: implications for conservation and food security. Oryx, 46, 196-203.

Wilkie, D.S. \& Carpenter, J.F. (1999) Bushmeat hunting in the Congo Basin: an assessment of impacts and options for mitigation. Biodiversity and Conservation, 8, 927-955.

Wilkie, D.S., Starkey, M., Abernethy, K., Effa, E.N., Telfer, P. \& Godoy, R. (2005) Role of prices and wealth in consumer demand for bushmeat in Gabon, Central Africa. Conservation Biology, 19, 268-274.

Wittemyer, G., Elsen, P., Bean, W.T., Burton, A.C.O. \& Brashares, J.S. (2008) Accelerated human population growth at protected area edges. Science, 321, 123-126.

\section{Biographical sketches}

Sery Gonedelé Bi is a geneticist and conservation biologist leading the conservation of Dassioko Sud and Port Gauthier Forest Reserves in coastal Côte d'Ivoire. INZA KONÉ is a primatologist and conservation biologist with interests in biodiversity and food security. JEAN Claude Béné is a primatologist and conservation biologist. He 
has conducted bushmeat surveys in Côte d'Ivoire and Liberia. E. ANDERSON BitTy is a primatologist and conservation biologist leading the conservation of Dassioko Sud and Port Gauthier Forest Reserves. Kou Assi AymaR's research interest is in genetics, and he was involved in the bushmeat market survey around the Dassioko Sud Forest Reserve. Yao Kouassi Alphonse is conducting an inventory of large mammals around the Dassioko and Port Gauthier Forest Reserves. Philippe Gaubert is an evolutionary biologist interested in conservation biogeography and the bushmeat trade throughout tropical Africa. 